\title{
Obituary Prof. Dr. Walter Marget
}

\author{
B. Belohradsky $\cdot$ D. Adam $\cdot$ F. Daschner $\cdot$ \\ R. Roos $\cdot$ M. Weiß
}

Published online: 12 November 2013

(C) Springer-Verlag Berlin Heidelberg 2013

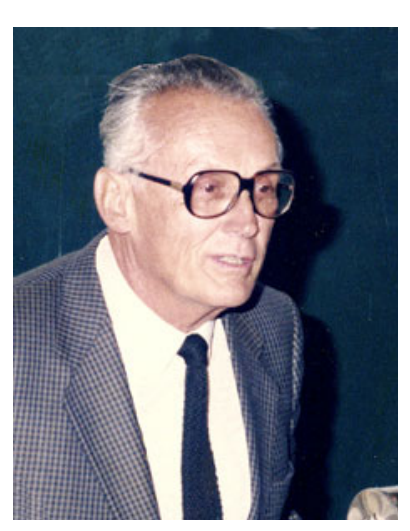

Prof. Dr. med. Walter Marget died in Munich on January 21, 2013.

From 1967 up until his retirement in 1986, Walter Marget was director of the Department of Antimicrobial Therapy and Immunology of Infectious Diseases in the University Children's Hospital of the Munich Ludwig Maximilians University Dr. von Haunersche Children's Hospital.

Walter Marget was born in Stuttgart on August 1, 1920. After graduating from high school in 1939, he commenced his studies in medicine and was a student in Innsbruck, Vienna and Heidelberg. During the war he served in the Alpine mountain infantry, at the North Cape and in Russia. He completed his studies by passing the state examinations in 1946. Thereafter, Walter Marget began his advanced

B. Belohradsky $(\bowtie) \cdot$ D. Adam · F. Daschner · R. Roos ·

M. Weiß

University Children's Hospital, Ludwig Maximilians University

Munich, Dr. von Haunersches Kinderspital, Lindwurmstrasse 4,

80337 Munich, Germany

e-mail: Bernd.Belohradsky@med.uni-muenchen.de microbiological studies as an assistant physician at the Heidelberg Institute for Hygiene and Microbiology, for which he was awarded his $\mathrm{PhD}$ in 1951.

His interest in clinical medicine and particularly pediatrics led Walter Marget to the Freiburg University Children's Hospital in 1951. In addition to his further studies for the rank of consultant pediatrician, Marget established his own specialized pediatric infectious diseases laboratory, a groundbreaking activity that prove to have a seminal influence on his subsequent scientific and clinical interests. This laboratory still exists today and all those working there are familiar with the name and pioneering spirit of its founder.

During the time he spent in Freiburg, Walter Marget dedicated himself to one particular scientific issue that has continued to increase in importance up to the present day; even if the field has undergone a change of direction: the epidemiology and pathogenesis of nosocomial Staphylococcus infections in newborn babies. In contrast to current research, work was not focused on the problems of resistance, but rather on the investigation of pathogen reservoirs, chains of infection and transmission. With the help of lysotyping - the differentiation between different bacterial species by bacteriophage standards-Marget was able to demonstrate hospital epidemics in newborns for the first time. It was for this work that he was awarded both his professorship and the German Society of Pediatrics Ernst Moro Prize in 1961.

Prof. Klaus Betke, Freiburg hematologist and Marget's friend, adopted the post of director at the Tübingen University Children's Hospital in 1962. Marget followed his like-minded companion to Tübingen and then, 5 years later, to the University Children's Hospital Munich. During his time in Munich, Marget developed the clinical and practical foundations of the research-based, patient- 
relevant study of infectious disease. Walter Marget founded the Department of Antimicrobial Therapy and Immunology of Infectious Diseases, which, within its further developed structure (microbiology and immunology of infectious diseases laboratory, research laboratories), still fulfills clinical and scientific functions today (diagnosis and treatment of infections and immune disorders, clinical hygiene).

Nosocomial Staphylococcus infections became the renewed focus of Marget's research interests at the beginning of the 1970s. Working together with Prof. Franz Daschner (subsequently of Freiburg University), the first externally funded epidemiological studies were carried out in South Germany. These studies were conducted in tight collaboration with working groups from the American Centers for Disease Control in Atlanta and made a major contribution to the establishment of professional clinical hygiene in Germany.

All other research directives in Marget's department were tightly coupled to the interests of his colleagues, including many research fellows with international roots. Ever increasingly, the common primary focus became the questions surrounding the mechanisms of host-defense. One example corollary of this shared focus was that the first bone marrow transplants were carried out on cancer and immune disorder patients in collaboration with the Department of Hematology and Oncology.

Walter Marget was a liberal department director who encouraged and supported the personal development of his colleagues. His scientific orientation demonstrated his originality, forward-thinking attitude and readiness to respond to new developments. During his lifetime, Marget considered the continued existence of his department to be of utmost importance, since he understood that pediatrics would not be possible without the study of infectious disease.

Marget supervised over $100 \mathrm{PhD}$ students. He supported the habilitation of his students (Dieter Adam, Franz Daschner, Bernd Belohradsky, Reinhard Roos, Michael Weiß) and thus the expansion of the scientific and clinical spectrum of his department. Within this circle, as in all aspects of his life, Walter Marget was open for every discussion and each new idea, an enrichment to every meeting, encouraging, often enthusiastic and always charismatic.

Walter Marget's liberal nature and love of life could be felt by everyone!

At the forefront of Marget's "personal" experimental interests during the latter years of his life, was the question of the role of endotoxins, the lipopolysaccharides of Gramnegative bacteria, in causing disease. His research activities led to several hundred scientific publications and over 30 book contributions.

In 1973, Walter Marget founded the English language journal "Infection". He went on to develop this into a widespread European publication and continued in his position of chief editor for several years after entering retirement.

Walter Marget was a member of numerous national and international societies in the fields of pediatrics, microbiology and infectious disease.

He was cofounder of the Paul-Ehrlich Society for Chemotherapy (Paul-Ehrlich-Gesellschaft für Chemotherapie, PEG), the German Society for Infectious Diseases (Deutsche Gesellschaft für Infektiologie, DGI) and the European Society for Pediatric Infectious Diseases (ESPID). In recognition of his unceasing promotion of Euro-American contacts, out of which firm personal friendships developed, he was an honorary member of the Pediatric Infectious Disease Society of America (PIDSA). He received the European Society for Clinical Microbiology and Infectious Diseases (ESCMID) Award for Excellence, the Paul-Ehrlich Society Medal of Honor, honorary membership of the German Society for Pediatric Infectious Diseases (Deutsche Gesellschaft für Pädiatrische Infektiologie, DGPI) and the Federal Cross of Merit.

In 1988, Marget's students Dieter Adam and Franz Daschner brought the Walter Marget Association for the Advancement of the Study of Infectious Diseases (Walter Marget Vereinigung zur Förderung der Infektiologie) into being. This project has enabled more than 50 young scholarship holders to spend time furthering their education and research interests in European and transatlantic centers. Which other institution has provided Germany with such a sustainable plan for the future of the study of infectious disease?

“The Dr.von Haunersche Children's hospital has lost a great physician, researcher and teacher. Prof. Marget had a seminal influence on the development of treatments for infectious diseases in newborn babies, children and adolescents-an influence that reached far beyond the Munich city limits. He supervised, supported and shaped generations of pediatricians. His humaneness and his contribution remain an example to us all." (taken from the obituary by Prof. Dr. Christoph Klein, director of the Munich clinic and his predecessors Prof. Dr. Beat Hadorn and Prof. Dr. Dr. h.c. Dietrich Reinhardt)

His former collaborators:

Bernd Belohradsky, Dieter Adam, Franz Daschner, Reinhard Roos, Michael Weiß 